\section{New drugs: who can afford them?}

\author{
Novos medicamentos: quem poderá pagar?
}

Nuevos medicamentos: ¿quién podrá pagarlos?

\footnotetext{
${ }_{1}$ Fundação Oswaldo Cruz, Rio de Janeiro, Brasil. 2 Escola Nacional de Saúde Pública Sergio Arouca, Fundação Oswaldo Cruz, Rio de Janeiro, Brasil.

Correspondence J. A. Z. Bermudez Fundação Oswaldo Cruz. Av. Brasil 4365, Casa Amarela, Rio de Janeiro, RJ 21040-09, Brasil.

bermudez@fiocruz.br
}

In 2014, the Chief Executive Officer of Bayer Corporation made a polemic statement: "No, because we did not develop this product for the Indian market, let's be honest. We developed thes product for Western patients who can afford this product, quite honestly. It is an expensive product, being an oncology product" 1 . The medicine at stake was the oncology drug sorafenib, indicated for some severe types of cancer.

A study published in November 2013 showed that twelve of the thirteen U.S. Food and Drug Administration (FDA)-approved cancer drugs in 2012 cost more than US\$100,000.00 per treatment in the United States 2. The high prices of new cancer treatments in 2013 triggered a reaction from a group of more than 100 chronic myeloid leukemia experts of all continents, who claimed these prices, in addition to being a major barrier to the access of patients to effective therapies, threatened the sustainability of national health systems of all countries 3 .

Early in 2015, England's National Health Service (NHS) decided to delay the adoption of the drug sofosbuvir for the treatment of hepatitis $\mathrm{C}$, despite its being considered cost-effective by NICE, the National Institute for Health and Care Excellence - the body responsable for technology assessment and incorporation in that country's public health system. Expenditure estimates for the public budget would be of 1 billion sterling
Jorge Antonio Zepeda Bermudez 1 Maria Auxiliadora Oliveira 2 Gabriela Costa Chaves ${ }^{2}$

pounds for 20,000 persons treated, considering there are 160,000 infected people in the country. Affordability prevailed over the cost-effectiveness assessment 4 .

A study on new treatments for hepatitis C 5 estimated that if all the 127,700 people eligible for treatment with sofosbuvir in France were to be treated, the cost would be higher than the budget for the Public Hospital System of Paris (Assistance Publique des Hôpitaux de Paris) in 2014. The reason is that the company Gilead, that markets the drug, launched it in the market at the cost of $€ 56,000$ per treatment; therefore, the total spending of treatment would reach 7.15 billion Euros. Of note is that sofosbuvir is used in combination with other high-cost mediciones, like another direct acting antiviral drug (DAA).

The challenge of sustainability of access to life-saving drugs has affected developed countries and is no longer limited only to developing countries. The issue is how countries whose governments are committed to providing universal access to new health technologies will face the challenge of financial sustainability. Who can afford it?

In Brazil, the 1990s were marked by different movements by society and the government pursuing of a comprehensive response to the HIV/ AIDS epidemics. With the development of the highly active antiretroviral therapy 6 , including 
combinations of drugs with different mechanisms of actions, the access to treatment became a central item in the government's agenda.

However, in 1996, the Brazilian Congress passed two laws that would be confronting, one another, in the near future. The first is Law 9,313/96 that ensured access to treatment to people living with HIV, which started the organization of pharmaceutical service at national level 7 .

The second is Law 9,279/96 that reforms the industrial property legislation to comply with the World Trade Organization's TRIPS Agreement (Agreement on Trade-Related Aspects of Intellectual Property Rights), which protects patents of pharmaceutical products and processes. The approval of this Law in 1996 meant its enforcement prior to the transition period established by the TRIPS agreement of January 2005, within the context of Brazil-United States bilateral relations. Since the end of the 1980s, the United States pressured the Brazilian government to grant patents of the pharmaceutical sector 8,9,10.

The immediate effect of this law in the financial sustainability of AIDS-treatment policy in Brazil was perceived at the end of the 1990s, when the new antiretroviral (ARV) drugs nelfinavir and efavirenz were adopted. In the subsequent years the Brazilian Ministry of Health adopted pricereduction measures/strategies for the new ARVs, culminating with the issuance of a compulsory license for efavirenz in 200711.

The procurement of ARV under monopoly raised awareness about the impact of high-cost medicines in the implementation of pharmaceutical services within the public health system so-called Brazilian Unified National Health System (SUS).

The adoption of a National Medicines Policy (Ordinance 3,916/98), the revision of the National List of Essential Medicines (RENAME 1998), and the National Policy on Pharmaceutical Services (Resolution 338/2004) complemented the regulations on medicines to be exceptionally dispensed - the so-called exceptional or high-cost drugs 12.

The list of drugs that were considered of exceptional dispensation was expanded, and later became specialized component of pharmaceutical services, whose financing and procurement are still shared between the states and the Brazilian Ministry of Health (Ordinance 2,981/2009). Caris et al. 13 showed that between 1993 and 2009, the number of medicines included in the list rose from 15 to 109.

Expenditures with drugs included as specialized components of pharmaceutical care represent some $45 \%$ of SUS total expenditure with medicines, that increased from $\mathrm{R} \$ 1.91$ billion in 2003 to $\mathrm{R} \$ 12.4$ billion in 2014 14. A study of the financing of specialized components of pharmaceutical services by SUS 15 shows an increase of $786 \%$ in expenditures with drugs included as specialized components by the Brazilian Ministry of Health in the period from 2003 to 201214 .

In 2011, SUS created the National Technology-Incorporation Committee (Conitec) (Law 12,401/11 and Decree 7,646/11) to advise the Brazilian Ministry of Health in evaluating requests for the inclusion of new technologies considering their evidence of efficacy and safety, and economic evaluation studies that also take into account long-term sustainability. In the period from July 2012 to December 2014, from a total of 148 requests analyzed, 65 technologies (including one expansion of use) were recommended and incorporated into the SUS 16.

There is no question that most of these technologies have the status of monopoly, probably because they are subject to patent protection (patent application filed or patent granted in the country), and that in the near future costs and public expenditure will be affected.

In the recent past, the Brazilian Ministry of Health proposed intervention strategies to regulate the market price, including negotiations with patent-owning companies, taking into account prices of reference in the international market, production cost estimates, and options to overcome patent-related barriers 17 .

The current scenario is more complex. First, because after 2005 countries that manufactured generic alternatives for the international market, which are important sources of reference prices, became fully compliant with the TRIPS Agreement. Many of their companies developed partnerships that involved voluntary licensing with multinational companies that excluded Brazil from the list of potentially beneficiary countries of the cheaper, generic types of drugs 18 . Secondly, because multinational companies are investing on biotechnology products, for which the challenge of having competition as a pricereduction strategy includes patent-related barriers and regulatory aspects 19 .

Despite the growing complexity of this scenario, it is now time to look at governmental strategies that were successful in the past to entertain possibilities for the future. The Global Strategy and Plan of Action on Public Health, Innovation and Intellectual Property (Resolution WHA 61.21) approved by World Health Organization (WHO) member countries in 2008, indicated elements that can be considered as policy options for access, innovation and development.

In this setting, the major issue currently under discussion worldwide is the high prices associated to the launching of new products 20,21,22. 
Not only for hepatitis C and oncology drugs, mentioned above, but also for new biotechnology products, certainly effective but perhaps not accessible, which poses new, bigger challenges to ensure universal access to health care at costs and prices affordable for the SUS.

\section{Contributors}

J. A. Z. Bermudez, M. A. Oliveira and G. C. Chaves participated in the discussion of the content, manuscript writing and revision.

\section{References}

1. Gokhale K. Merck to Bristol-Myers face more threats on India patents. http://www.bloomberg. com/news/articles/2014-01-21/merck-to-bristolmyers-face-more-threats-on-india-patents (accessed on $15 / \mathrm{Feb} / 2015)$.

2. Light DW, Kantarjian H. Market spiral pricing of cancer drugs. Cancer 2013; 19:3900-2.

3. Experts in Chronic Myeloid Leukemia. The price of drugs for chronic myeloid leukemia (CML) is a reflection of the unsustainable prices of cancer drugs: from the perspective of a large group of CML experts. Blood 2013; 121:4439-42.

4. Boseley S. Hepatitis C drug delayed by NHS due to high cost. The Guardian 2015; 20 jan. http://www. theguardian.com/society/2015/jan/16/sofosbuvir hepatitis-c-drug-nhs (accessed on 15/Feb/2015). 
5. Londeix P. New treatments for hepatitis $C$ virus strategies for achieving universal access. Paris: Médecins Du Monde; 2014.

6. Scheffer M. Coquetel: a incrível história dos antirretrovirais e do tratamento da AIDS no Brasil. São Paulo: Editora Hucitec/Sobravime; 2012.

7. Oliveira MA, Esher A. Acesso universal ao tratamento para as pessoas vivendo com HIV e AIDS no Brasil. In: Bermudez JAZ, Esher A, organizadores. Acceso a medicamentos: derecho fundamental, papel del estado. Rio de Janeiro: Escola Nacional de Saúde Pública Sergio Arouca, Fundação Oswaldo Cruz; 2004. p. 233-50.

8. Tachinardi MH. A guerra das patentes - conflito Brasil X EUA sobre propriedade intelectual. Rio de Janeiro: Paz e Terra; 1993.

9. Bermudez JAZ. Remédio: saúde ou indústria? A produção de medicamentos no Brasil. Rio de Janeiro: Editora Relume-Dumará; 1992.

10. Bermudez JAZ. Indústria farmacêutica, estado e sociedade: crítica da política de medicamentos no Brasil. São Paulo: Editora Hucitec; 1995.

11. Grangeiro A, Teixeira L, Bastos FI, Teixeira P. Sustentabilidade da política de acesso a medicamentos antirretrovirais no Brasil. Rev Saúde Pública 2006; 40 Suppl:60-9.

12. Silva RCS, Bermudez JAZ. Medicamentos excepcionais ou de alto custo no Brasil. In: Bermudez JAZ, Esher A, organizadores. Acceso a medicamentos: derecho fundamental, papel del estado. Rio de Janeiro: Escola Nacional de Saúde Pública Sergio Arouca, Fundação Oswaldo Cruz; 2004. p. 203-31.

13. Carias CM, Vieira FS, Giordano CV, Zucchi P. Medicamentos de dispensação excepcional: histórico e gastos do Ministério da Saúde do Brasil. Rev Saúde Pública 2011; 45:233-40.
14. Departamento de Assistência Farmacêutica e Insumos Estratégicos, Secretaria de Ciência, Tecnologia e Insumos Estratégicos, Ministério da Saúde. Serviços farmacêuticos na atenção básica à saúde. Brasília: Ministério da Saúde; 2014. (Cuidado Farmacêutico na Atenção Básica; Caderno 1).

15. Fonseca EM, Costa NR. Federalismo, complexo econômico-industrial da saúde e assistência farmacêutica de alto custo no Brasil. Ciênc Saúde Coletiva 2015; 20:1165-76.

16. Comissão Nacional de Incorporação de Tecnologias no SUS, Ministério da Saúde. Recomendações sobre as tecnologias avaliadas. http://conitec.gov. br/index.php/decisoes-sobre-incorporacoes (accessed on 15/Feb/2015).

17. Ministério da Saúde. Política Federal de Assistência Farmacêutica: 1990 a 2002. Brasília: Ministério da Saúde, 2002. (Série B. Textos Básicos de Saúde).

18. Médecins Sans Frontières. Untangling the web of antiretroviral price reduction. 13th Ed. Geneva: Médecins Sans Frontières; 2010.

19. EvaluatePharma. World preview 2014, outlook to 2020. http://info.evaluategroup.com/rs/evaluate pharmaltd/images/EP240614.pdf (accessed on 10/ Feb/2015).

20. Cohen J. Advocates protests the cost of a hepatitis C cure. Science 2013; 342:1302-3.

21. Câmara dos Deputados. A revisão da Lei de Patentes: inovação em prol da competitividade nacional. Brasília: Edições Câmara; 2013.

22. Bermudez JAZ. Acesso a medicamentos - direito ou utopia? Rio de Janeiro: e-papers; 2014. 